\title{
Brand Loyalty of Baby Diaper Products
}

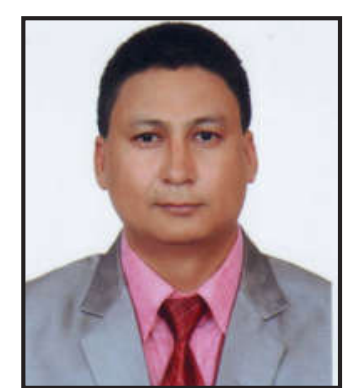

Dr. Sajeeb Kumar Shrestha*

\begin{abstract}
This study tries to measure the factors influencing brand loyalty of baby diapers in Kathmandu City. Primary cross section data were collected using structured questionnaires. 200 working mothers were chosen as sample of the study. Reliability analysis, descriptive statistics and regression analysis was done to filter the questions, to summarize the data and to test the hypotheses. This research confirmed convenience, product quality, design, brand experience and brand image factors are important factors for brand loyalty of baby diaper products. Price has no support for brand loyalty.
\end{abstract}

Key Words: Brand Loyalty, Kathmandu City, Baby Diaper Products

\section{Introduction}

Brand loyalty motivates the consumer that their product has the required qualities and this becomes the base for a future purchase behavior. Holt (2004) argues that brand loyalty is the consumer's willingness to stay with a brand when competitors come knocking with offerings that would be considered equally attractive had not the consumer and brand shared a history. Kabiraj and Shanmugan (2011) argued brand loyalty as the consumer's conscious or unconscious decision, expressed through intention or behavior, to repurchase a brand continuously. Thiele and Bennett (2001) also support the consumers show different attitude towards durable goods and consumption goods.

Son (2010) described brand loyalty as deeply held commitment to re-buy or re-patronize a preferred product in the future. Mokhtar, Amjad and Husain (2000) argue brand loyalty generate profit and future growth of the organization. Brand loyalty has been described as behavioral responses to the brand (Jacoby \& Kyner, 1973). Brand loyalty means customer purchase the product repeatedly in the future. Customer purchases the liked brand most often (Aawan \& Rehman, 2014). Brand Loyalty is a context where the consumer fears purchasing and consuming product from another brand which he does not trust.

Baby diaper industry is the fastest growing industries in the world. One of the main influence of growing diaper industry is that it is largely fueled by the growing baby population in developing nations, where the disposable income of parents have also increased considerably at the same time. In addition, growing number of women entering into mainstream workforce

* Lecturer, Shanker Dev Campus, Tribhuvan University, Nepal 
has helped the baby care market to grow, as the average disposable income of the family has grown. Baby care market has also witnessed a growing trend in baby specific products, especially baby cosmetics \& diapers, in terms of ingredients used and poses no threat to baby's health.

Several companies are competing in baby care products in Nepalese market. These are Johnson \& Johnson, Farlin, Unicharm, Huggies, Pampers, Soft Love and Cudlers etc. This research is going to focus in disposable pant style diapers which are currently competing in Nepalese market (Sharma, 2014). Altogether five different brands are competing in disposable pant style diapers in Nepal (Sharma, 2014). They are Unicharm (India), Huggies (USA), Soft Love (Srilanka), Cuddlers (Nepal) \& Sweety (Indonesia) (Sharma, 2014). Among them, Unicharm India is at top with its product MamyPoko Pants and the second is Huggies, third Cuddlers, fourth Soft Love and last Sweety based on their sales in Nepal (Sharma, 2014).

Convenience means something is comfortable and easy to use. It is a key driver to loyalty. Product quality means the features that deliver the satisfaction to customers. It is conformance to requirement (Russell \& Taylor, 2006). Design is the visual appearance that attracts customers to brand (Frings, 2005) and more on fashion related (Duff, 2007). Product design motivates customer to ask more about products (Sproles \& Kendall, 1986). Price is viewed as an important factors that is basis for comparing products, brand switching and allow to pay premium prices to products (Cadogan and Foster, 2000; Keller, 2003). Brand experience is the subjective responses related about how consumer feel about brand related stimuli like to sensation brand color, shape, typeface, background design, brand websites, and brand characteristic (Oliver, 1999). Brand image move customer to new zone that is brand loyalty (Lazarevic, 2011). It is an intangible aspect of brand in the mind of customer (Keller, 2003). Chen and Myagmarsuren (2011) argued brand image is an important factor when consumers compare products.

Nowadays consumer has various alternative choices to select the brand so the marketers are facing very tough competition to sell their products. At present the consumption of diaper is highly increasing. No research was found on investigating the brand loyalty of baby diaper products in Nepal. So, this research is designed to measure the brand loyalty of baby diaper products in the Nepalese context.

The study is based on consumers brand loyalty in diaper based on Kathmandu valley. The research question was designed as followed,

What are the factors influencing brand Loyalty on baby diaper products?

The aim of the study is to fulfill the following issues:

To analyze the frequency of purchase of diaper products.

To examine the factors affecting the brand loyalty of diapers products. 
The research determined the factors influencing brand loyalty of customers towards baby diaper products. Some limited of this research were,

This study was limited to working moms in Kathmandu City.

Basically, primary cross section data were collected to fulfill the objectives of the research.

Survey was done in Kathmandu City.

\section{Research Framework}

The conceptual framework is the basis or foundation upon which the study is established.

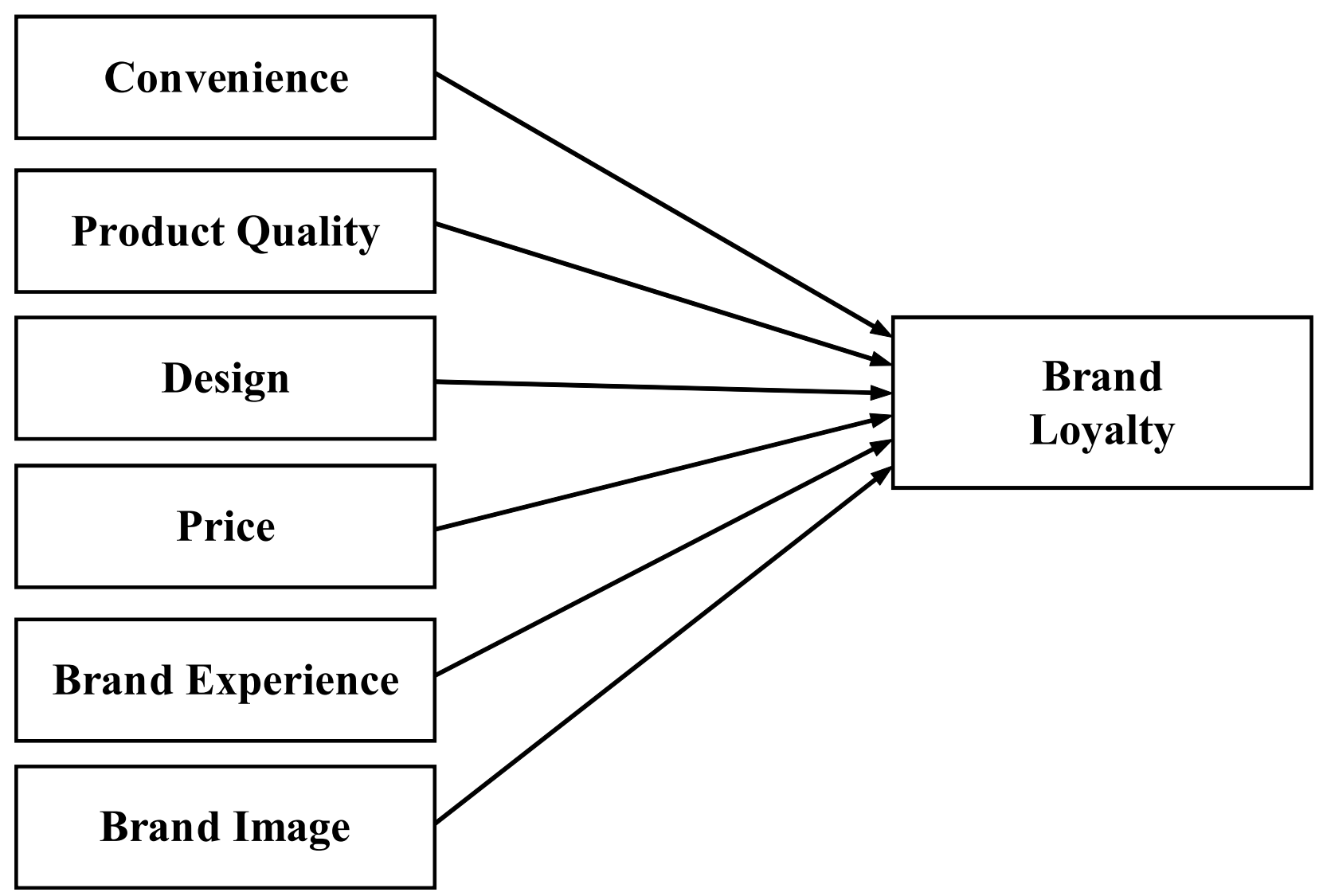

Figure 1: Research Framework

\section{Variable Definition}

The main variables were convenience, product quality, design, price, brand experience, brand image and brand loyalty. Independent variables were convenience, product quality, design, price, brand experience and brand image. Dependent variable was brand loyalty. 
Table 1: Variable Identification

\begin{tabular}{|c|c|c|c|}
\hline Relationship & $\begin{array}{c}\text { Independent } \\
\text { variable }\end{array}$ & $\begin{array}{c}\text { Dependent } \\
\text { variable }\end{array}$ & Hypothesis \\
\hline $\begin{array}{c}\text { Convenience and Brand } \\
\text { Loyalty }\end{array}$ & Convenience & Brand Loyalty & $\mathrm{H}_{1}$ \\
\hline $\begin{array}{c}\text { Product Quality and } \\
\text { Brand Loyalty }\end{array}$ & Product quality & Brand Loyalty & $\mathrm{H}_{2}$ \\
\hline Design and Brand Loyalty & Design & Brand Loyalty & $\mathrm{H} 3$ \\
\hline Price and Brand Loyalty & Price & Brand Loyalty & $\mathrm{H} 4$ \\
\hline $\begin{array}{c}\text { Brand Experience and } \\
\text { Brand Loyalty }\end{array}$ & Brand Experience & Brand Loyalty & $\mathrm{H} 5$ \\
\hline $\begin{array}{c}\text { Brand Image and Brand } \\
\text { Loyalty }\end{array}$ & Brand Image & Brand Loyalty & $\mathrm{H} 6$ \\
\hline
\end{tabular}

\section{Hypotheses}

Based on the research framework on Figure 2, following hypotheses have been formulated:

H1: Convenience significantly influence brand Loyalty of customer.

H2: Product Quality significantly influence brand Loyalty of customers.

H3: Design significantly influence brand Loyalty of customers.

H4: Price significantly influence brand Loyalty of customers.

H5: Brand experience significantly influence brand Loyalty of customers.

H6: Brand image significantly influence brand Loyalty of customers.

\section{Research Methods}

The objective of the research was to measure the brand loyalty on baby diaper products. To obtain the objective, this research adopted positivists approach. In this regard, quantitative research method was applied. There are some reasons of following quantitative method. First, quantitative method is appropriate when hypotheses are developed (Creswell, 2009). Second, sample of the research should be representative to obtain the research objective. Quantitative research is suitable while large samples are taken. Third, to test the quantitative method survey research was done to assure the use of the positivist methodology.

Descriptive and causal research design was applied in this research. Constructs were based on literature and studied in detailed.

Subject of the study was diaper purchasing consumers in Kathmandu City. The respondents of this survey were the working mothers reside in different locations in the Kathmandu City who used to prefer branded product for their baby's and are more concerned in health and 
modern products with more disposable income. 200 consumers were selected who used to purchase baby's diaper for their kids.

Convenience sampling method was used for collecting data. Structured questionnaires were designed to entertain the large sample as suggested by Kline (1998). Eldred (1987) suggests that for most types of marketing research projects, samples of 100 to 200 persons are sufficient to yield useful results. For large sample standard errors are small enough to be of practical use (Malhotra \& Birks, 2003). Primary cross-section data were collected in this research. Structured questionnaires based on Likert scales were distributed to gather the data.

Respondents were approached at different locations in Kathmandu City and requested to fulfill the questionnaires. A short brief about the research is communicated and questionnaires were distributed to fill up and collected.

Reliability analysis was done to check the consistency of the questionnaires filled. Descriptive statistics was done to summarize the data. Multiple regression was run to test hypotheses assumed.

86 percent respondents were female and 14 percent respondents were male. Majority of the respondents were female. Majority of the respondents were in the age between 20-30 years of 65 percent followed by respondent's age between 30-40 years of 28 percent. This showed mid aged young generated were more inclined towards purchasing diaper products. 51 percent of the respondents were having bachelor degree and 39 percent having master degree.

\section{Regression Model}

$\mathrm{BL}=\alpha+\beta_{1} \mathrm{CO}+\beta_{2} \mathrm{PQ}+\beta_{3} \mathrm{DE}+\beta_{4} \mathrm{PR}+\beta_{5} \mathrm{BE}+\beta_{6} \mathrm{BI}+\varepsilon_{\mathrm{i}}$

Where,

Where, $\mathrm{BL}=$ Brand Loyalty; $\alpha=$ Constant ; $\beta_{\mathrm{i}}=$ Slope of the regression model; $\mathrm{CO}=$ Convenience; $\mathrm{PQ}=$ Product Quality; $\mathrm{DE}=$ Design; $\mathrm{PR}=$ Price; $\mathrm{BE}=$ Brand Experience;

$\mathrm{BI}=$ Brand Image, and $\varepsilon=$ Error term.

\section{Results and Discussion}

\section{Use of Diaper Products}

Fourty five percent respondents were using the diaper products for one to two years followed by 36 percent of respondents were using the diaper products by less than one year.

\section{Reliability Analysis}

Reliability analysis based on Cronbach's alpha determines the internal consistency or average correlation of items in a survey instrument to gauge its reliability. 
The value of Cronbach's Alpha coefficient $(\alpha)$ lies from 0 to 1 and may be used to describe the reliability of the scale items (Nunnaly \& Bernstein, 1994).

Table 2: Reliability Analysis

\begin{tabular}{|c|c|c|}
\hline Code & Particulars & Cronbach's Alpha \\
\hline CO & Convenience & .793 \\
\hline PQ & Product Quality & .748 \\
\hline DE & Design & .845 \\
\hline PR & Price & .834 \\
\hline BE & Brand Experience & .712 \\
\hline BI & Brand Image & .766 \\
\hline BL & Brand Loyalty & .751 \\
\hline
\end{tabular}

Table 2 showed the results of reliability of measurement scales of constructs. Cronbach's Alpha coefficients were highly reported and showed excellent fit (George \& Mallery, 2009; Nunnaly \& Bernstein, 1994).

\section{Descriptive Statistics}

Descriptive statistics is used to help describe, show or summarize data in a meaningful way so that patterns are seen and can be analyzed. Descriptive statistics is only to identify pattern but is not for the purpose of making conclusions or to reach conclusions regarding any hypotheses. They are simply a tool to describe the data collected through the questionnaire.

Table 3: Descriptive Statistics

\begin{tabular}{|c|c|c|}
\hline Constructs & Mean & Std. Deviation \\
\hline Convenience & 3.960 & .57 \\
\hline Product Quality & 3.820 & .75 \\
\hline Design & 3.287 & .78 \\
\hline Price & 3.666 & .77 \\
\hline Brand Experience & 3.935 & .71 \\
\hline Brand Image & 3.985 & .70 \\
\hline Brand Loyalty & 3.831 & .69 \\
\hline
\end{tabular}

Table 3 showed the mean value of convenience, product quality, design, price, brand experience, brand image, and customer satisfaction were communicated above 3 . This showed that respondents viewed these variables have influence on forming purchase and loyalty of diaper products. 


\section{Regression Analysis}

\section{Regression Assumption Tests}

Regression assumption tests were done before running the regression analysis. Normality, linearity, multicollinearity, and independence of error test showed no problems on data. So, regression analysis was done.

Table 4: Regression Analysis

\begin{tabular}{|c|c|c|}
\hline Explanatory Variable & Coefficient of $\beta$ & Sig. \\
\hline Constant & .209 & .153 \\
\hline Convenience (CO) & .053 & .035 \\
\hline Product Quality (PQ) & .096 & .044 \\
\hline Design (DE) & .010 & .043 \\
\hline Price (PR) & -.053 & .229 \\
\hline Brand Experience (BE) & .208 & .000 \\
\hline Brand Image (BI) & .243 & .000 \\
\hline \multicolumn{3}{|c|}{$\begin{array}{l}R=0.73 ; R^{2}=0.63 ; \text { Adj. } R^{2}=0.61 ; S . E .=.3504 ; F-\text { Value }=145.36 ; \\
p \text {-value of } F \text { test }=0.000 . \\
\text { Sig. at } 5 \% \text { level }\end{array}$} \\
\hline \multicolumn{3}{|c|}{ Model: $\mathrm{BL}=.209+.053 \mathrm{CO}+.096 \mathrm{PQ}+.010 \mathrm{DE}-.053 \mathrm{PR}+.208 \mathrm{BE}+.243 \mathrm{BI}$} \\
\hline
\end{tabular}

Table 4 showed F-value and p-value of regression model was 145.36 and 0.000 which was significant at $5 \%$ level of significance. So, the model fitted linearly.

R square of this model was .61 or $61 \%$ that means the model is predicted $61 \%$ in brand loyalty by variation of explanatory variables (convenience, product quality, design, price, brand experience, and brand image).

\section{Hypotheses Testing}

H1: Convenience significantly influence brand Loyalty of customers.

Sig. value of convenience is 0.035 which is significant at $5 \%$ level of significance. So, $\mathrm{H} 1$ is accepted. Convenience significantly influence brand loyalty on baby diaper products.

H2: $\quad$ Product Quality significantly influence brand Loyalty of customers.

Sig. value of product quality is .044 which is significant at 5\% level of significance. So, H2 is accepted. Product quality significantly affects brand loyalty on baby diaper products. 
H3: Design significantly influence brand Loyalty of customers.

Sig. value of design is .043 which is significant at $5 \%$ level of significance. So, H3 is accepted. Design significantly affects brand loyalty on baby diaper products.

H4: Price significantly influence brand Loyalty of customers.

Sig. value of price is .229 which is not significant at $5 \%$ level of significance. So, H4 is not accepted. Price does not significantly affect brand loyalty on baby diaper products.

H5: Brand experience significantly influence brand Loyalty of customers.

Sig. value of brand experience is .000 which is significant at $5 \%$ level of significance. So, $\mathrm{H} 5$ is accepted. Brand experience significantly influence brand loyalty on baby diaper products.

H6: Brand image significantly influence brand Loyalty of customers.

Sig. value of brand image is .000 which is significant at $5 \%$ level of significance. So, H6 is accepted. Brand image significantly influence brand loyalty on baby diaper products.

\section{Conclusion}

This research is done to measure the brand loyalty of baby diaper products in Kathmandu City. The result is consistent with Chen and Myagmarsuren (2011), Sproles and Kendall (1986) that product quality and brand image had influence on brand loyalty of baby diaper products. Convenience, product quality, design, brand experience and brand image factors are most determining factors for brand loyalty of baby diaper products in Kathmandu City. Major of the respondents were using baby diaper products from more than a year. Respondents prefer baby diaper because it is conveniently purchasing, product quality is good, design is new and performing well, customer experienced more and trust gained from it and superior brand image of the baby diaper products. Diaper marketers should consider convenience, product quality, design, brand experience and building brand image of diaper products.

\section{References}

Aawan,, A.G., \& Rehman, A. (2014). Impact of customer satisfaction on brand loyalty- An empirical analysis of home appliances in Pakistan. British Journal of Marketing Studies, 2(8), 18-32.

Cadogan, J. W., \& Foster, B. D. (2000). Relationship selling and customer loyalty: An empirical investigation. Marketing Intelligence and Planning, 185-199.

Chen, C. F., \& Myagmarsuren, O. (2011). Brand equity, relationship quality, relationship value, and customer loyalty: Evidence from the telecommunications services. Total Quality Management \& Business Excellence, 22(9), 957- 974. 
Cresswell, J.W. (2009). Mapping the field of mixed methods research. Journal of Mixed Methods Research, 3, 95-108.

Eldred, G. (1987). Real estate: Analysis and strategy. New York: Harper \& Row.

Frings, G. S. (2005). Fashion: From concept to consumer (8th ed.). New Jersey: Pearson/Prentice Hall.

George, D., \& Mallery, P. (2009). SPSS for Windows, step by step (8th ed.). Delhi, Patparganj: Dorling Kindersley (India) Pvt. Ltd.

Holt, D. (2004). How brands become icons: The principles of cultural branding. Massachusetts: Harvard Business School Press.

Jacopy, J., \& Kyner, D. B. (1973). Brand loyalty versus measurement and management. Journal of Marketing Research, 10, 1-9.

Kabiraj, S., \& Shanmugan, J. (2011). Development of a conceptual framework for brand loyalty: A Euro-Mediteranean perspective. Journal of Brand Management, 285-299.

Keller, K. L. (2003). Strategic brand management: building, measuring and managing brand equity. New Jersey: Prentice Hall.

Kline, R.B. (1998). Principles and practice of structural equation modelling. New York: The Guilford Press.

Lazarevic, V. (2011). Encouraging brand loyalty in fickle generation Y consumers. The Australia Emerald Group Publishing Limited,13(1), 45-61.

Liu, Y. (2007). The long-term impact of loyalty programs on consumer purchase behavior and loyalty. Journal of Marketing, 71(4), 19-35.

Malhotra, N., \& Birks, D. (2003).Marketing research: An applied approach. Harlow, England: Prentice Hall.

Mokhtar, A., Amjad, D., \& Husain, N. ( 2000). Evaluating functional relationship between image, customer satisfaction and customer loyalty using general maximum entropy. Total Quality Management, 11(4/5/6), 826- 829.

Nunnally, J.C., \& Bernstein, I. H. (1994). Psychometric theory (3 ${ }^{\text {rd }}$ ed.). New York, NY: McGraw-Hill Inc.

Oliver, R. (1999). Whence consumer loyalty? Journal of Marketing, 63, 33-34.

Russell, R. S., \& Taylor, B. W. (2006). Operation management: Quality and competitiveness in a Global Environment (5th ed.). River Street: John Wiley \& Sons Inc.

Sharma, S. (2014). Internal sales report on Nepalese diaper market. Kathmandu, Nepal: Overseas Marketing Pvt.Ltd. 
Son, K. (2010). Resistance to brand switching when a radically new brand is introduced: a social identity theory perspective. Journal of Marketing,74, 128- 146.

Sproles, G. B., \& Kendall, E. L. (1986). A methodology for profiling consumer decision -making design. The Journal of Consumer Affairs, 20, 267-279.

Thiele, S., \& Bennett, R. (2001). A brand for all seasons? A discussion of brand loyalty approaches and their applicability for different markets. Journal of Product and Brand Management, 10(1), 25-37. 